\title{
Macroeconomic Policies to Address Informality: A Two-pronged Strategy to Foster Dynamic Transformations that Reduce Informality
}

\author{
Radhika Lal
}

A significant proportion of jobs created in developing countries are precarious, without benefits and protections and can be viewed as being part of a socalled informal economy. This includes employment in the so-called informal sector and informal jobs in the formal sector.

By definition and scope, the informal economy is thus quite heterogeneous in nature and the factors making for its expansion and contraction can be seen to be quite varied. Factors include policies governing business, labour regulation and the provisioning of and access to social security benefits and insurance, as well as the nature of macroeconomic and industrial policies in place. At stake is the overall health of the economy, its growth and its potential to create jobs and entrepreneurial opportunities.

In the literature and practical discussion of informality, the focus appears to have mostly been on the changing nature of the labour market ${ }^{1}$ and institutional factors, in particular, the business regulatory environment and the choices of small operators in the informal sector and employers in the formal sector. ${ }^{2}$ Here, 'choice' for the principal actors tends to be framed along the singular axis of the 'cost of doing business' and the need for flexibility (e.g. Perry et al. 2007; Maloney 2004). It is often assumed that were flexibility permitted - both in terms of the business environment and in terms of hiring, deploying and firing of workers - there would likely be less movement into the informal economy and, perhaps, greater movement out of it.
This same worldview also appears to characterise the labour market foundations of conventionally prescribed macroeconomic frameworks wherein it is assumed that the growth of informality derives from imperfections principally in the 'labour market' and constraints imposed by the regulatory environment. In this framework, following the introduction of constrictive fiscal and monetary policies, it is assumed that employment will return to the prevailing level after an initial decline or even grow if wages fall to a level that is 'optimal' for market clearing. Optimality from the point of view of securing equilibrium is defined without any consideration of the specificities of what it takes for labour to be supplied on a sustainable basis or the processes and factors that allow for a movement towards greater value-added in production. In practice, it is possible that the equilibrating wage turns out to be a poverty wage; that the new level of employment could be one at which economic activity involves reduced investment in key sectors or patterns of sectoral development with the potential for a downward spiral in the future and a likelihood of a further decline in formal employment opportunities.

Evidence also suggests that while some regulatory policies and labour policies may constrain formal sector employment growth and entrepreneurship, and therefore would need reform, there is no unambiguous case for informality that can be made on these grounds. ${ }^{3}$ Part of the reason for this lies in the fact that labour and wages cannot be viewed only as a cost. In addition to the fact that the case 
for labour market regulation can be made on both efficiency and equity grounds, the role of wages in contributing to aggregate demand needs to be recognised. As Bhaduri points out:

The shift in focus from the demand to the cost or supply side has serious consequences, particularly in terms of level of employment ... it might be efficient on the microeconomic scale of a single corporation or enterprise, but such policies may also turn out to be counter-productive and inefficient on the macroeconomic scale at the same time, by precipitating a decline in demand, and higher unemployment. ${ }^{4}$

(Bhaduri 2005: 11)

Recognition also needs to be accorded to how the dynamic structure of the economy could also be adversely affected by changes in the distribution from formal to informal activities and towards a more unequal income distribution within the formal economy. For example, growing inequality would likely shift demand towards luxury goods and imports, on the one hand, and subsistence goods produced by informal workers, on the other, with a potential hollowing out of the middle level of mass consumption and investment which have a potential for realising higher productivity levels, lower prices and increased growth over time.

The reflections below seek to bring back a focus on some of the macroeconomic determinants of informality that work through affecting the productive sector and dynamic transformations in the economy. The importance of aggregate demand, particularly investment, for influencing the level of (formal) employment and the degree of informality will be highlighted. Targeted policies and focused investment, particularly in so far as it contributes to strengthening capabilities, will be stressed as key determinants of the creation of 'good' jobs.

In general, a sound macroeconomic environment is seen as essential for development, growth and investment. However, in practice, the unequivocal importance assigned to variables constituting the macroeconomic environment relative to more specific policies and targeted investments is being questioned. It is increasingly becoming evident that the interrelationships between the real labour market, investment, structural change and growth and the real impact of macroeconomic policies are complex and, in many ways, are still unclear in both developed and currently developing economies. Structural conditions in the economy - ranging from the concrete drivers of growth, the strength of job creating sectors, levels of indebtedness, capabilities and innovation etc..$^{5}$ - may play a large part in determining the nature of response of the economy to fiscal and monetary stimuli and disincentives. Further, given the potentially changing pattern and weight of the various inter-linkages, there may be both practical/conjunctural and inherent/systemic limits to the efficacy of the various policies over time. ${ }^{6}$

It is not surprising then that there are complications arising from the 'one-size-fits all' and restricted mix of target and policy instruments that are de facto possible and de jure permitted. The complications have not only to do with misunderstanding the nature of the likely impact in the short run and underestimating its efficacy in the context of open economies, but also, in effect, ignoring the impact on more long-run outcomes, such as the impact on private investment, which underlie employment creation.

In the short run, as has often been pointed out, conventional monetary policies, in particular, have been obsessed with ensuring 'low' inflation, often without adequate sensitivity as to the common and specific causes of inflation in developing countries, e.g. supply-side shocks such as a rise in the price of oil, as opposed to demand-push factors that can more adequately be addressed through microeconomic or targeted mechanisms. The necessity and the possibility of having perfectly adequate country-specific inflation targets and policy instruments, as opposed to a one-size-fits-all approach, have only recently been recognised (Pollin et al. 2007; Epstein 2007; Ghosh 2006). ${ }^{7}$ The bluntness of the interest rate in controlling inflation, with higher interest rates occasionally resulting in aggravated inflationary pressures, has also only recently been acknowledged. ${ }^{8}$

Fiscal and other structural policies - in particular, structural adjustment policies - can be less blunt as instruments given that they can be more targeted in their focus. For example, subsidies and taxes can target particular constituencies or sectors. However, the conventionally-prescribed package has been very restrictive in scope and focus. Public investment has been viewed as 'crowding-out' private investment or as fuelling inflation through out-of-control and 
unproductive deficit spending, and therefore needs to be curtailed. While the theory anticipates a decline in production and employment in the shortrun as a result of stabilisation measures, the dismal growth and job creation that have often continued for decades afterwards have raised a number of issues regarding the efficacy of the conventional package. Questions abound concerning the appropriateness of the conceptual foundations and assumptions, e.g. assumption that the economy reaches full-employment equilibrium in the absence of labour market 'imperfections'; that growth in developing countries is mostly capital constrained not demand constrained; and that growth is savings-led with the need for capital market liberalisation rather than investment-led and based on perceived and realised opportunities and the level of aggregate demand. ${ }^{9}$ Questions have also been raised with regard to its relevance given the particular conditions faced by many developing economies. These include the nature of operative constraints, which relate more to perceptions of risk and institutional gaps rather than savings constraints per se, and the existence of large informal labour markets and under-employment.

This has not only shifted attention to a broad mix of economic and institutional policies essential for poverty reduction and growth, but has also served to highlight the developmental role of the state and the productive roles of public investment, e.g. the role of productive public investment in facilitating a potential net crowding-in of private investment ${ }^{10}$ through provision of infrastructure, through creating demand for its products, and though enhancing the availability of essential goods and services which the private sector may under-supply contexts because of high investment costs or myopic decision-making in which long-run returns are systematically undervalued (Roy et al. 2006; Oya and Weeks 2004; Weeks and McKinley 2007; Pollin et al. 2006; Weeks and Roy 2004; Mallick 2002). Further, the de facto limits on fiscal and monetary policy when capital flows are permitted - e.g. the need to keep interest rates high to keep capital flowing in - and the potential detrimental effects of these volatile flows on public debt and investment are increasingly being pointed to (UNCTAD 2006; Bhaduri 2005).

Thus far, there has been allusion to, but not much discussion of, the role of public policy in the context of fostering structural transformation and innovation which can sustain growth and employment, particularly in the face of increased global integration. Conventional macroeconomic and structural adjustment policies take physical factor (labour and capital) endowments to be the primary determinants of a country's comparative advantage, which, it is assumed, should also govern the pattern of trade. However, evidence suggests that competitiveness lies in a mix of capabilities and that competitive advantage is often 'acquired' through a process of learning and focus on developing capabilities, technological and innovation capabilities in particular. As Sanjaya Lall points out:

most trade theories, including new trade theory, assume that technology can be imported and used by developing countries without further effort, cost or uncertainty. In other words, there is no learning process involved: if there is learning, it is passive and automatic learning-by-doing. (Lall 2002: 9)

Yet to the extent learning is an active purposeful process that involves institutions, investments and collaborations with the public sector to address market failures and information gaps, it is one of the first things that is likely to suffer in a situation of economic crisis and cutbacks in investment. The sectoral competitiveness and employment response to liberalisation, often proposed in combination with restrictive macroeconomic policies, is dependent upon the state that the emerging sectors are in at the time that the economy is opened up. Analysis suggests that:

industries which had been dynamic during the import substitution era continued to be dynamic in terms of production, exports and investment ... industries which were near maturity when the reform started, such as aerospace in Brazil, benefited from liberalization as the competitive pressure that emerged made them more efficient. By contrast, those inefficient, or those at infancy stage, could not well survive. Faced with severe import competition, some industries, including labour industries in a number of countries, suffered ... Trade liberalization has led to the development and re-orientation of the industrial sector in accordance with static comparative advantage, with the exception of industries that were near maturity.

(Shafaeddin 2005: 27) 
To the extent the development of dynamic capabilities in industry are critical for facilitating an overall transformation of the economy (Piper 1999), not investing in such capabilities can throw a country back and increase the reliance on natural-resource and agriculture sector, albeit often at a lower level of value-added than might otherwise have been possible had investments in backward and forward linkages and technological capabilities been made (Piper 1999).

In the case of public investment as well, it turns out that the more productive components are likely to suffer both because the payoffs are more long-term than the conventional accounting period, and hence are harder to justify under current fiscal rules (Roy et al. 2006; Bhaduri 2005), and also because other more 'current' aspects of investment may be politically more difficult to cut than long-run investments.

The above analysis and reflections suggest the importance of getting the content of macroeconomic policies right based on a diagnostic/constraint-based analysis (Heintz 2006), adopting a flexible approach in keeping with the actual conditions prevailing in the country in question (Pollin et al. 2007) and focusing on laying the capabilities and foundations for growth and the generation of 'good jobs' (Lall 2002; Bhaduri 2005). Investment priorities and the effects of policies on the dynamic structure of the economy need to be considered not just ensuring balance of price and financial variables in the short-run since these have implications for growth, employment and poverty reduction. Given the objective of enhancing employment creation, it may seem counter-intuitive to suggest a focus on the diversification of the industrial sector which is often 'capital-intensive' (and may result in 'jobless growth' if output does not grow at a faster rate than productivity) rather than only focusing on 'labour-intensive' sectors and activities e.g. agriculture, services, construction. However, the assumption is that a multi-faceted approach needs to be adopted to lay the foundations for more sustainable employment creation. ${ }^{11}$ The use of targeted policies taxation, trade, and credit instruments - and institutional initiatives support to cluster development and production networks would be included and could help to encourage spatially balanced development and a variety of 'viable' upstream and downstream linkages to more labour-intensive sectors and small scale producers (Heintz 2006; Bateman 2006).
It has been suggested thus far that if space for relevant policy innovations could be secured at both the macroeconomic and trade policy levels, and adequate levels of public and private investment generated in the economy, then the likelihood that the economy would both generate new 'good jobs' and help transform some 'bad jobs' into formal 'good jobs' will be higher. However, given the currently high and growing levels of informality in developing country economies, this is unlikely to be sufficient to deal with the scale of informality at present. There is thus a need for a two-pronged strategy (Chen et al. 2004) to both pull people out of the informal economy as well as to improve conditions within it.

The first prong, as indicated above, involves the deployment of macroeconomic, trade and industrial policies to further the dynamic and structural transformation of the formal economy to support employment creation that can be viable, sustainable, and able to cope with competitive pressures and be focused on developing the national economy. The second prong would involve, on the one hand, the deployment of fiscal and other targeted financing and business development and related support policies to support infrastructure development, financial services, and technological upgrading in the informal sector and the strengthening of production and marketing linkages with the formal sectors in agriculture, industry and services (Nanavaty 2005). It would also involve policy experimentation and openness to a variety of options to secure increased access to jobs ${ }^{12}$ and to the delivery of financial, social, business and social security support services, while providing incentives to move towards formalisation. At the same time, some sort of basic floor of social protection should be secured regardless of job status (e.g. see exploration by Francois Bourguignon (2005) to decouple social security from job status). Social security access is central not only from the point of view of equity but also for enhancing efficiency.

While a significant proportion of production undertaken in the informal sector is likely to be at a subsistence or small-scale trading level, in many instances there are already strong linkages with the formal sector given the trend to shift production to or to outsource from non-unionised and informal sector enterprises, in some cases to erstwhile competitors in the informal sector. Strengthening the position of workers and small operators and traders in the informal production sector involves 
support to bottom-up approaches that seek to renegotiate transactions within the informal sector and with the formal sector on terms that are more beneficial to informal sector workers and producers. These involve: (1) fostering increased awareness, access to information, and capacity development to improve product quality and access markets; (2) access to financing/micro-leasing arrangements to facilitate technology upgrading and innovation; (3) the move from support to the SME towards strengthening the web of local, regional, national inter-linkages and support structures, e.g. through development of economic clusters and networks to take advantage of dynamic linkages and secure economies in purchasing, accessing services and marketing opportunities (UNIDO 2004) and through support to targeted job-creation linked to the development strategy through, for example, an employment guarantee schemes and support to approaches that build on community-support and collaborative inter-linkages. While rights-based schemes can be viewed as important in their own right, combined with a good local development strategy, they can help to address both demand and supply sides of the equation through raising incomes of the poorest and catalysing the development of infrastructure and local markets (Bhaduri 2005).

For an example of innovative approaches consider the following: The 'Self Employed Women's Association in India' (SEWA) organised informal sector women producers to first form production groups and then to federate into local economic federations and cooperatives to better negotiate and articulate with the formal sector. Through the combination of strengthening the workers' own organisations and through the setting up of technical support organisations, such as the SEWA Trade Facilitation Centre (STFC) and Gram Mahila Haat (SGMH), small producers are able to more effectively compete as well as to secure a larger share of the benefits. STFC and SGMH support includes the design of marketing strategies and formation of partnerships with agro-processing, food processing, and heavy chemical industries nationally on more productive terms to the informal sector producers such that they are also able to receive technical support to upgrade quality and production processes and in turn to assure the bulk provision of standardised produce (Nanavaty 2005). SEWA has also demonstrated the viability of providing insurance and security benefits to women and small-scale producers and workers in the informal sector, which can help to sustain productive involvement and further equity. Aside from policy support and institutional initiatives to enable small producers to secure a larger share of the value-added generated along these supply chains, support to redefining labour regulations so as to improve conditions of work and employment opportunities and also enhance labour mobility are also key (Heintz 2006).

Transforming the informal sector will also likely involve a different approach to strengthening entrepreneurship and providing SME support than currently prevails (Bateman 2006). Conventionally, the scope of what counts as a business is quite narrow (often it does not include cooperatives and mixedownership and hybrid forms that might be more appropriate to pro-poor and local development approaches), financing is largely at the level of microfinance focused on quick returns with the assumption that even business development support centres can function on a pure market driven basis of cost-recovery. However, the experience of successful initiatives in the now developed economies (e.g. Italy, Spain, Japan, China) suggests that support was both multi-faceted, targeted at providing support at various stages of the life cycle of firms and often integrated into the strategic planning frameworks of local governments and banking institutions:

This developmental imperative also included an urgent need for a specifically local industrial policy approach. Crucially, this local industrial policy would involve the establishment of a stock of pro-active local development institutions that could support new ventures and marshal the best of the existing stock of microenterprises and SMEs towards higher levels of productivity, innovation and technology intensity, encourage vertical and horizontal interaction and information exchange, and provide direct encouragement for new microenterprises and SMEs to 'organically' emerge ...

(Bateman 2006: 29)

While the replicability of the success of 'industrial districts' in Emilia-Romagna in Northern Italy, its relevance at present, as well as the nature of labour conditions that prevailed are debated issues (see Pyke et al. 1990), lessons can still be drawn from that experience particularly regarding multi-faceted government strategies and the role of cooperatives 
and cooperation for catalysing 'development from below' and contributing to poverty reduction (e.g. Birchall 2003). Particularly interesting are a range of support and technical assistance initiatives that were coordinated through regional and local government economic development departments. They included, for example, the Regional Agency for the Economic Evaluation of the Territory (ERVET) that gathered information, carried out R\&D and provided a set of 'real' or targeted services through a number of service centres aimed at the needs of very small firms, which often required highly targeted services in order to be able to reach different market segments and undertake technology upgrading and transfer (Capecchi 1990). The use of tax incentives helped to encourage capitalisation and hence enhance competitiveness (e.g. Law 904 of 16 December 1977). Strong regional development banks that helped to provide low-cost capital and local government support to an array of initiatives undertaken by the cooperative membership bodies themselves, such as by the Legacoop (Italy's largest cooperative membership body) supported the growth of existing and new co-ops. Legacoop also began to assist in the conversion of failing investordriven companies into cooperatives and the establishment of venture funds to support new cooperatives. Public purchasing programmes, technical training, and the establishment of a range of business associations and marketing cooperatives helped to generate collective economies of scale for the sectors identified as having high potential for growth. In addition, the regional and local governments provided comprehensive social services, including local transport, day-care centres and training, to allow women to enter the formal sector economy. An expanding cooperative sector was viewed as helping these regions to rapidly and equitably re-industrialise (Pyke et al. 1990).

Other examples include Town Village Enterprises (TVEs) in China, a hybrid form of rural industrial enterprise that combined ownership by local communities, management on market principles, and strong ties to local governments through the township-village government (TVG). The TVG either exercised direct managerial authority or delegated this responsibility to professional managers (Agia 2004). Viewed by some as a transitional form that achieved its peak in the late 1990s, the TVEs were primarily labour-intensive enterprises that manufactured a variety of goods ranging from coal, canned goods, and clothing to electronic and construction materials. They were known for their achievements in the areas of output, employment, export growth, productivity, technology upgrading, and often for sustained profitability (Harvie 2000, cited in Agia 2004). While there are issues relating to its human resource structures (Ding et al. 2000) with contracts often being precarious, workers also befitted as local citizens benefited not only from the TVGs' support of communal programmes in education and infrastructure development, for example, but also from the profits retained for further development of the firm and for the local employment growth that it permitted.

To conclude, a structural policy approach to realise an informality-aware employment agenda would work by addressing aggregate demand and capabilities dimensions at national as well as regional/local levels and focus on changing the terms of engagement within the informal sector. It would emphasise the importance of strategic and local planning and development financing as regards development of the formal sector but also with the objective of addressing informality. Even at the local level, it suggests the need for a proactive industrial and financing policy and a development focus, rather than an overwhelming reliance on micro-finance as a tool to support SME growth as is often the case. As Bateman points out:

Mclntyre (2003) emphasises that there is little evidence to suggest that market automaticity and the associated free entry of large numbers of simple microenterprises as per the microfinance model, has anywhere produced a sustainable economic and social development trajectory. In general, the mass entry of 'shallow' microenterprises tends to correlate with a subsequently reduced likelihood of a sustainable growth and development trajectory taking root. The rapid proliferation of 'shallow' microenterprises and SMEs creates a set of adverse 'initial conditions' that, through a number of different mechanisms and feedback loops, tends to permanently hold back, if not entirely block, any further deepening of the local economic development trajectory. Some of the most important factors arising are: innovation processes are very weak, longer run investment is reduced because it is absorbed elsewhere in 'quick return' projects, human capital is also diverted 
into 'quick return' areas ('learning to trade rather than learning to produce'), and technology diffusion and transfer fails to emerge because

\section{Notes}

1 For example, expansion of the definition of the workplace to include the domestic sphere; exploration of gender-specific and other factors leading to changing division of time between formal work and reproduction/home work; and with informality, the incorporation of diverse employment contracts and social security entitlements.

2 At one level, this may appear to be a disciplinary division of labour between sociology and economics, but similar conceptual foundations for the labour market find their way into conventional macroeconomics. On the edges, moving to the centre, are more substantial engagements both regarding a critique of the content and focus of macroeconomic policies, but also engagement with those working on globalisation, structural adjustment and employment.

3 For issues relating to World Bank specification of cost of doing business, see Berg and Cazes (2007) For an assessment of lack of significant relationship between rights and labour standards and informal employment, see Galli and Kucera (2004), Sengenberger (1990) and Baker et al. (2004).

4 See Bhaduri (2005: 11) and Bhaduri and Marglin (1990). Bhaduri (2005) points out: Consequently, unless either higher investment or increased export demand makes up for that reduction in consumption demand in a regime of investmentor export-led growth, the problem of insufficient aggregate demand due to such policies of labour market flexibility would depress the level of economic activity and employment.

5 On the importance of technological and other capabilities and related investments, see Lall (2002), Shafaeddin (2005), van der Hoeven and Taylor (2000), Atukeren (2006) and Bartzokas (2007).

6 These limits come from the continued effectiveness of the instruments over time, as well as from the limits of various policy instruments in open economy contexts and from the changing roles of global players and their ability to secure global stability when global good and national interests do not coincide. See most recently, George Soros (22 January 2008) and Chandrasekhar and Jayati Ghosh (19 February there is no constituency of support for it. (Bateman 2006: 17)

2002) for the limits of current US financing and credit policies, on the one hand, and the potential of Japan to use public deficit and investment policies, on the other. The implications of the growing role of China and its need to ensure stability of its own currency and growth and export processes in these turbulent times also points to the potential for global instability in light of the US sub-prime debt crisis.

7 Epstein (2007) points to earlier research (Pollin and Zhu 2006: 606) that concludes that 'more generally, that for developing countries, inflation below about 15 per cent is not harmful for economic growth, and can, indeed be beneficial. Ghosh (2006) suggests that much depends upon the quality of macroeconomic management rather than there being some unequivocal type of relation between inflation and growth: 'It is worth noting that the Chinese economy has grown very rapidly for nearly 30 years, with only moderate inflation. Even in the current year, when the Chinese economy is apparently growing by more than 10 per cent in real terms, inflation has been only 1.4 per cent at an annual rate'.

8 In fact, in addition to not being able to effectively address factors fuelling inflation, it is possible that the policy could worsen it, e.g. lead to increase in public indebtedness through raising the cost of existing debt; lead to an over-valued currency with implications for competitiveness and the current account deficit, to address which a further rise of interest rates might be called for to attract inflows of capital. See submission from Bryan Gould (2007).

9 On assumption of savings-led growth and potential pitfalls for growth of liberalisation of financial sector, see UNCTAD (2006); for reference to issues relating to conceptual framework in the context of growth, see Oya and Weeks (2004).

10 For example, see Léonce Ndikumana (2005). His research indicates that the net impact of an increase in public investment financed by domestic borrowing is likely to be positive for South Africa: 'For example, if the increase in the public investment-GDP ratio from 5 per cent to 6 per cent described above was entirely financed by domestic debt, the crowding-out effect of the 
associated domestic borrowing would be a 1.7 per cent decline in private investment and the net impact would be a 3.9 per cent increase in private investment'. For indications for why there may be differential impact in different contexts, see Atukeren (2006).

\section{References}

Agia, Aziza (2004) Alternatives Innovative, Significant Scale Models of Community Asset-Building: Learning from International Experience, College Park, MD and Washington DC: Democracy Collaborative and the National Centre on Economic and Security, www.community-wealth.org/_pdfs/ articles-publications/cross-sectoral/report-agia.pdf

Atukeren, Erdal (2006) Politico-Economic Determinants of the Crowding-in Effects of Public Investments in Developing Countries by Swiss Institute for Business Cycle Research, www.kof.ethz.ch/publications/ science/pdf/wp_126.pdf

Baker, Dean, Glyn, Andrew, Howell, David and Schmitt, John (2004) Unemployment and Labour Market Institutions: The Failure of the Empirical Case for Deregulation, New York: CEPA (New School University), www.newschool.edu/cepa/papers/ archive/cepa200404.pdf

Bartzokas, Anthony (2007) 'Revisiting the Concept of Industrial Policy', paper prepared for the UNIDO Sanjaya Lall Memorial Conference, New Delhi, 10 September, www.unido.org/filestorage/download?file_id=75204

Bateman, Milford (2006) 'The Informalisation of the $\mathrm{BiH}$ Economy and the Role of the Microfinance Model Economic Policy Research Unit (EPRU)', Seminar 'Balkan Economies: Studies on NonStandard Phenomena', 26 September, UNITIC, Sarajevo, Bosnia and Herzegovina, www.microfinancegateway.org/redirect. php?mod $\mathrm{e}=$ link\&id=36282

Berg, Janine and Cazes, Sandrine (2007) The Doing Business Indicators: Measurement Issues and Political Implications, International Labour Organisation (ILO), www.ilo.ch/public/english/employment/ download/elm/elm07-6.pdf

Bhaduri, A. (2005) Macroeconomic Policies for Higher Employment in the Era of Globalization, ILO Employment Strategy Papers 2005/11, Geneva: International Labour Office, www.ilo.org/public/ english/employment/strat/download/esp200511.pdf (accessed 12 February 2008)

Bhaduri, A. and Marglin, S. (1990) 'Unemployment and the Real Wage: The Economic Basis of
11 See Piper (1999) and Shafaeddin (2005) for the importance of focusing on the industrial sector perse.

12 For example, employment guarantee schemes.

Contesting Political Ideologies', Cambridge Journal of Economics 14: 375-93

Birchall, Johnston (2003) Rediscovering the Co-operative Advantage: Poverty Reduction Through Self-Help, Geneva: International Labour Organisation (ILO), www.ilo.org/dyn/empent/docs/F1406653842/ poverty\%20-\%20coops\%20birchall\%20090103.pdf (accessed 12 February 2008)

Bourguignon, François (2005) 'Development Strategies for More and Better Jobs', presentation at the conference 'Help Wanted: More and Better Jobs in a Globalized Economy', organised by the Carnegie Endowment for International Peace, 14 April, Washington DC, http://siteresources.worldbank.org/DEC/Resources/ 84797-1104785060319/bourguignondevelopment strategiesformoreandbetterjobs. PDF (accessed 12 February 2008)

Capecchi, Vittorio (1990) 'A History of Flexible Specialisation and Industrial Districts in EmiliaRomagna', in Frank Pyke, Giacomo Becattini and Werner Sengenberger (eds), Industrial Districts and Inter-firm Cooperation in Italy, Geneva: International Labour Organisation (ILO)

Chandrasekhar, C.P. and Ghosh, Jayati (2002) 'Is the World Headed for Depression Again?', Hindu Business Line, 22 February, www.thehindu businessline.com/2002/02/19/stories/200202190 0161300.htm (accessed 12 February 2008)

Chen, M.J., Vanek, J. and Carr, M. (2004) Mainstreaming Informal Employment and Gender in Poverty Reduction, London: Commonwealth Secretariat, www.wiego.org/publications/ Mainstreaming\%2OInformal\%20Employment\%20 and\%20Gender\%20in\%20Poverty\%20Reduction.htm (accessed 12 February 2008)

Ding, D.Z., Ge Lan and Warner, M. (2000) A New Form of Chinese Human Resource Management? Personnel and Labour Management Relations in Chinese Township and Village Enterprises: A CaseStudy Approach, Judge Institute of Management Working Paper WP 33/2000, Cambridge: Cambridge University, http://www.jbs.cam.ac.uk/ research/working_papers/2000/wp0033.pdf (accessed 12 February 2008) 
Epstein, Gerald (2007) Central Banks, Inflation Targeting and Employment Creation, ILO Employment Analysis and Research Unit Economic and Labour Market Analysis Department 2007/12, Geneva: International Labour Office, www.ilo.int/public/ english/employment/download/elm/elm07-2.pdf (accessed 12 February 2008)

Galli, Rossana and Kucera, David (2004) 'Labour Standards and Informal Employment in Latin America', World Development 32.5: 809-28, http://training.itcilo.it/decentwork/staffconf2003/ documents/Galli\%20Kucera\%2OInformal\%20Short .pdf (accessed 12 February 2008)

Ghosh, Jayati (2006) 'Why Inflation Still Matters', Frontline 23.24: 02-15 December, www. hinduonnet.com/thehindu/fline/fl2324/ stories/20061215001809600.htm (accessed 12 February 2008)

Gould, Bryan (2007) Submission from Bryan Gould to the Finance and Expenditure Select Committee's Inquiry into the Future Monetary Policy Framework, 17 July, www.bryangould.net/ id37.html (accessed 12 February 2008)

Harvie, Charles (2000) 'Business Alliances, Organizational Change and Township and Village Enterprises', in Charles Harvie (ed.), Contemporary Developments and Issues in China's Economic Transition, New York: St Martin's Press (cited in Democracy Collaborative and the National Centre on Economic and Security 2004), www.uow.edu.au/ content/groups/public/@web/ @commerce/ (a)econ/documents/doc/vow012253.pdf (accessed 12 February 2008)

Heintz, James (2006) 'Growth, Employment, and Poverty Reduction', Discussion Paper prepared for the workshop: Growth, Employment, and Poverty Reduction, held at the Department for International Development (DFID), London, 17 March

Lall, Sanjaya (2002) 'The Employment Impact of Globalisation in Developing Countries', prepared for the International Policy Group (IPG) unit of the International Labour Office in the context of a United Kingdom DFID funded project on Understanding Globalization, Employment and Poverty Reduction, http://hdr.undp.org/docs/ training/oxford/readings/2004/lall\%202003a.doc (accessed 12 February 2008)

Mallick, Sushanta K. (2002) 'Determinants of Longterm Growth in India: A Keynesian Approach', Progress in Development Studies 24, London: The Royal Institute of International Affairs, 306-24, www.qmul.ac.uk/ bsw070/PDS02.pdf (accessed 12 February 2008)

Maloney, William F. (2004) 'Informality Revisited', World Development 32.7: 1159-78

Mclntyre, Robert and Dallago, Bruno (eds) (2003) Small and Medium Enterprises in Transitional Economies, London: Palgrave Macmillan in association with the UN University/World Institute for Development Economics Research (WIDER)

Nanavaty, Reema (2005) From Local to Global and Informal to Formal: Entering Mainstream Markets, UNU/Wider Discussion Paper 2005/02

Ndikumana, Léonce (2005) Can Macroeconomic Policy Stimulate Private Investment in South Africa? New Insights from Aggregate and Manufacturing Sector-level Evidence, Political Economy Research Institute Working Paper 2005-14, Amherst, MA: University of Massachusetts, www. peri.umass.edu/ fileadmin/pdf/working_papers/working_papers_10 1-150/WP106.pdf (accessed 12 February 2008)

Oya, Carlos and Weeks, John (2004) Poverty Reducing Employment in Africa: Review of Case Studies and an Analytical Framework, Report to the UNDP and the ILO, www.undp.org/poverty/docs/ employment/undp-ilo-oya-weeks. doc (accessed 12 February 2008)

Perry, Guillermo; Maloney, William Fi; Arias, Omar S: Fajnzylber, Pablo; Mason, Andrew D. and Saavedra-Chanduvi, Jaime (2007) Informality: Exit and Exclusion, Washington DC: World Bank http://web.worldbank.org/WBSITE/EXTERNAL/C OUNTRIES/LACEXT/O, , contentMDK:21345369 p agePK:146736 piPK:146830 theSitePK:258554,0 O.html (accessed January 2008)

Piper, Ute (1999) Deindustrialization and the Social and Economic Sustainability Nexus in Developing Countries: Cross-Country Evidence on Productivity and Employment, CEPA Working Paper 10, March, New York: CEPA (New School University), www. newschool.edu/cepa/papers/archive/cepa011 O.pdf (accessed 12 February 2008)

Pollin, Robert; Epstein, Gerald; Heintz, James and Ndikumana, Léonce (2006) An Employmenttargeted Economic Programme for South Africa, Country Study 1, Brasilia: International Poverty Centre (UNDP), www.undp-povertycentre.org/ publications/reports/South\%20Africa.pdf (accessed 12 February 2008)

Pollin, Robert; Githinji, Mwangi and Heintz, James (2007) An Employment-Targeted Economic Program for Kenya, Brasilia: International Poverty Centre 
(UNDP), www.undp-povertycentre.org/publications/ reports/Kenya.pdf (accessed January 2008)

Pollin, Robert and Andhong Zhu (2006) 'Inflation and Economic Growth: A Cross-country Nonlinear Analysis', Journal of Post Keynesian Economics, Summer 28.4: 593-614

Pyke, Frank, Becattini, Giacomo and Sengenberger, Werner (eds) (1990) Industrial Districts and Inter-firm Cooperation in Italy, Geneva: International Labour Organisation (ILO)

Roy, Rathin, Heuty, Antoine and Letouzé, Emmanuel (2006) 'Fiscal Space for Public Investment: Towards a Human Development Approach', paper prepared for the G-24 technical meeting, Singapore, 13-14 September, www.g24.org/rroy0906.pdf (accessed 12 February 2008)

Sengenberger, Werner (1990) The Role of Labour Standards in Industrial Restructuring: Participation, Protection and Promotion, International Institute for Labour Studies Discussion Paper, DP/19/1990, Geneva: International Labour Office, www.ilo.ch/ public/english/bureau/inst/papers/1990/dp19/ index.htm\#3 (accessed 12 February 2008)

Shafaeddin, S.M. (2005) Trade Liberalization and Economic Reform in Developing Countries: Structural Change or De-Industrialization?, UNCTAD Working Paper 179, Geneva: United Nations Conference on Trade and Development (UNCTAD),

www.unctad.org/Templates/Download.asp?docid $=6371 \&$ lang $=1 \&$ intltem ID=2068 (accessed 12 February 2008)

Soros, George (2008) 'The Worst Market Crisis in 60 Years', Financial Times, comment and analysis,
22 January, www.ft.com/cms/s/0/24f73610-c9le11dc-9807-000077b07658. html (accessed January 2008)

UNCTAD (2006) Trade and Development Report 2006, Geneva: United Nations Conference on Trade and Development (UNCTAD), www.unctad.org/ Templates/webflyer.asp?docid=7183\&intltemID=25 08\&lang $=1$ (accessed December 2007)

UNIDO (2004) Industrial Clusters and Poverty Reduction: Towards a Methodology for Poverty Reduction and Social Impact Assessment of Cluster Development Initiatives, Vienna: United Nations Industrial Development Organisation (UNIDO) van der Hoeven, Rolph and Taylor, Lance (2000) 'Management Employment and Labour Market Policies in an Era of Structural Adjustment', Handbook on Development Policy and Management, Geneva: International Labour Organisation (ILO), www.ilo.org/public/english/employment/strat/ publ/hoevenl.htm

Weeks, John and McKinley, Terry (2007) The Macroeconomic Implications of MDG-Based Strategies in sub-Saharan Africa, Policy Research Brief 4, October, Brasilia: International Poverty Centre (UNDP), www.undp-povertycentre.org/ pub/IPCPolicyResearchBrief4.pdf (accessed 12 February 2008)

Weeks, John and Roy, Rathin (2004) Making Fiscal Policy Work for the Poor, UNDP, www.undp.org/ poverty/docs/prm/FisSynth_MarO4.doc (accessed 12 February 2008) 